\title{
Evaluation of Bio-agents against Sclerotinia sclerotiorum causing Stem Rot of Broccoli
}

\author{
Gajendra Pratap Singh and Bhupendra Kumar Singh*
}

Department of Plant Pathology, Vegetable Section, Kalyanpur

C.S. Azad University of Agriculture and Technology, Kanpur, India

*Corresponding author

\section{A B S T R A C T}

Keywords

Broccoli, Stem rot, Sclerotinia

sclerotiorum, Bioagents

Article Info

Accepted:

17 September 2019

Available Online:

10 October 2019

\begin{abstract}
The stem rot of Broccoli (Brassica oleracea var. italica Plenk) caused by Sclerotinia sclerotiorum (Lib.) de Bary is increasingly drawing attention as a destructive disease. Intensive use of fungicides for protection of crops from disease is not only injurious to human health but also polluting the environment. The effect of different bio-agents was evaluated against stem rot of broccoli caused by Sclerotinia sclerotiorum as an alternate approach to manage the disease. Different fungal and bacterial bio-agents were isolated from sclerotia of test organisms and rhizosphere of broccoli and tested against the fungus. Among them fungal bio-agent Coniothyrium minitans formed maximum inhibition zone (16 mm) while bacterial bio-agents Pseudomonas fluorscens created minimum (10 mm) inhibition zone in in vitro. In field experiments minimum disease incidence was observed with Coniothyrium minitans followed by Trichoderma viride, whereas rest of the bioagents proved least effective.
\end{abstract}

\section{Introduction}

Broccoli (Brassica oleracea var. italica Plenk) belongs to Family Brassicaceae is a cole crop gaining importance in India due to its nutritional value. It is an herbaceous annual grown for its edible flower heads which are used as vegetable. The broccoli plant has a thick green stalk or stem, which gives rise to thick, leathery, oblong leaves which are grayblue to green in color. The plant produces large branching green flower heads covered with numerous white or yellow flowers. The crop is prone to several diseases of fungal origin but recently it has been observed that the stem rot caused by Sclerotinia sclerotiorum (Lib.) de Bary is increasingly drawing attention as a destructive disease. Intensive use of fungicides for protection of crops from disease is not only injurious to human health but also polluting the environment. Therefore, it was the demand of the time to develop an alternate, effective and safe approach to manage the disease. In view of importance of the disease, an attempt has been made to find out the suitable bio agents against the disease. So, present studies were undertaken to know the effect of bio-agents in 
managing the disease in vitro and under field conditions.

\section{Materials and Methods}

To find out the relative effect of bio-agents in inhibiting the growth of the pathogen in vitro, different fungal and bacterial bio-agents were isolated from sclerotia of test organisms and rhizosphere of broccoli and tested against the fungus through dual culture technique as described by Dhingra and Sinclaire (1995). For this purpose $20 \mathrm{ml}$ of sterilized PDA was aseptically poured in sterilized Petri dishes and allowed to solidify. Five $\mathrm{mm}$ disc of isolated fungi and bacteria and test pathogen , each cut with the help of sterilized cock borer were placed on solidify PDA in such a manners so that they may be placed on either of the side of Petri dish $60 \mathrm{~mm}$ apart. Plates were inoculated without pathogen served as control.. These were incubated at $20 \pm 1^{0} \mathrm{C}$. The data on the mechanism of interaction between the test pathogen and other microorganisms were observed. The commercial formulation of bio agents were prepared according to the different techniques suggested by scientists (Jeyrajan and Ramakrishnan, 1991; Mc-Qiilken and Whipps, 1995). The culture filtrates were prepared with the $9 \mathrm{~mm}$ discs of bio agents inoculated in 3 flasks each separately an incubated at $25^{\circ} \mathrm{C}$ for two weeks, which was further use for testing.

To evaluate the effect of fungal bio agents as seed dresser against the pathogen, pot experiment was conducted at glass house of department during Rabi season. The earthen pots were filled with sterilized soil and $5 \mathrm{~g}$ fungal inoculum was incorporated in each pot. The moist seeds of broccoli were treated with each bio agents @ $4 \mathrm{~g}$ per kg of seeds. The treated seeds were shade dried and sown in pots on next day. After 20-25 days seedlings were ready to transplant. Before transplanting, the seedlings were dipped in culture filtrate for 2 hour before transplanting in to the earthen pots were prepared earlier. Each treatment was replicated thrice and untreated seeds and seedlings served as control a total of 24 plants were tested in each treatment. The observations on disease intensity were recorded and analyzed statistically.

The pot experiment was conducted to evaluate the effectiveness of bio-agents as soil applicants in the glass house of the department for two consecutive years. The earthen pots were filled with $5 \mathrm{~kg}$ soil taken from the same field in which disease was present in the previous year. The formulations of bio-agents were incorporated in to pots @ $8 \mathrm{~g} /$ pot three days before transplanting of the seedlings. Each treatment was replicated thrice. Untreated pots were also maintained for served as control. The data on disease intensity were recorded and analyzed statistically.

\section{Results and Discussion}

\section{Effect of bio-agents against pathogen in vitro}

The result presented in Table 1 indicated that the mycelia growth of the pathogen was reduced to great extent by extensive growth of the antagonists in the the dual culture. The inhibition of mycelia growth of the test pathogen by Coniothyrium minitans, Trichoderma viride, Trichoderma harzianum, Trichoderma virens and Pseudomonas fluorescens was observed visually by clearcut demarcating zones between their respective mycelia growth. Coniothyrium minitans formed maximum inhibition zone $(16 \mathrm{~mm})$ followed by Trichoderma viride, Trichoderma harzianum, Trichoderma virens while bacterial bio-agents Pseudomonas fluorescens created minimum $(10 \mathrm{~mm})$ inhibition zone. However, the sclerotia production in the 
culture with bio-agents was much less as compared to the check. Rotting of the sclerotia of the pathogen was frequently observed by Coniothyrium minitans. Thus, growth of the pathogen and formation of sclerotia were greatly reduced by parasitizing habit and antibiosis of bio-agents. The present investigation is in conformity of finding reported by Ahmed and Tribe (1977) who noticed Coniothyrium minitans as mycoparasites of Sclerotinia sclerotiorum. Similar findings were also observed by Bhardwaj et al. (1992 and Budge et al. (1995).

\section{Effect of bio-agents as seed dresser}

It is revealed from Table 2 and its corresponding figure 1 , that all the bio-agents were significantly superior in controlling the disease over control. Maximum disease control was observed with the formulation of Coniothyrium minitans treated seeds and seedlings. The second best bio-agent was Trichoderma viride which was statistically at par with Coniothyrium minitans. Trichoderma harzianum reduced the disease to a great extent.

Table.1 Effect of bio-agents against the Sclerotinia sclerotiorum in vitro

\begin{tabular}{|c|l|c|c|c|}
\hline \multirow{2}{*}{$\begin{array}{c}\text { S. } \\
\text { No. }\end{array}$} & \multicolumn{1}{|c|}{ Bio-agents } & \multicolumn{2}{|c|}{ Average radial growth (mm) } & $\begin{array}{c}\text { Inhibition zone } \\
(\mathbf{m m})\end{array}$ \\
\cline { 3 - 4 } & & Bio-agent & Pathogen & \\
\hline 1. & Coniothyrium minitans & 62 & 12 & 16 \\
\hline 2. & Trichoderma viride, & 64 & 12 & 14 \\
\hline 3. & Trichoderma harzianum, & 67 & 10 & 13 \\
\hline 4. & Trichoderma virens & 69 & 9 & 12 \\
\hline 5. & Pseudomonas fluorescens & 30 & 50 & 10 \\
\hline 6. & Control & - & 90 & - \\
\hline & CD at 5\% & - & - & $\mathbf{2 . 4 4}$ \\
\hline
\end{tabular}

Table.2 Effect of bio-agents as seed dresser against the Sclerotinia sclerotiorum

\begin{tabular}{|l|l|c|c|c|}
\hline S.N. & Bio-agents & $\begin{array}{c}\text { No. of plants } \\
\text { tested }\end{array}$ & $\begin{array}{c}\text { Av. No. of plants } \\
\text { affected }\end{array}$ & $\begin{array}{c}\text { Average Disease } \\
\text { Intensity (\%) }\end{array}$ \\
\hline 1. & Coniothyrium minitans & 24 & 4 & 16.67 \\
\hline 2. & Trichoderma viride, & 24 & 5 & $24.06)$ \\
\hline 3. & Trichoderma harzianum, & 24 & 7 & $(27.11)$ \\
\hline 4. & Trichoderma virens & 24 & 9 & 29.17 \\
\hline 5. & Control & & & $32.68)$ \\
\hline & CD at 5\% & 24 & 11 & $(37.70)$ \\
\hline
\end{tabular}


Table.3 Effect of bio-agents as soil applicant against Sclerotinia sclerotiorum

\begin{tabular}{|c|c|c|c|c|}
\hline \multirow[t]{2}{*}{ S.N. } & \multirow[t]{2}{*}{ Bio-agents } & \multicolumn{2}{|c|}{ Average Disease Intensity (\%) } & \multirow{2}{*}{$\begin{array}{l}\text { Pooled Disease } \\
\text { Intensity }(\%)\end{array}$} \\
\hline & & I year & II Year & \\
\hline 1. & Coniothyrium minitans & $\begin{array}{c}14.32 \\
(22.19)\end{array}$ & $\begin{array}{c}15.36 \\
(23.03)\end{array}$ & $\begin{array}{c}14.84 \\
(22.82)\end{array}$ \\
\hline 2. & Trichoderma viride, & $\begin{array}{c}16.08 \\
(23.61)\end{array}$ & $\begin{array}{c}17.02 \\
(24.34)\end{array}$ & $\begin{array}{c}16.55 \\
(23.99)\end{array}$ \\
\hline 3. & $\begin{array}{l}\text { Trichoderma } \\
\text { harzianum, }\end{array}$ & $\begin{array}{c}20.42 \\
(26.94)\end{array}$ & $\begin{array}{c}21.38 \\
(27.54)\end{array}$ & $\begin{array}{c}20.90 \\
(27.20)\end{array}$ \\
\hline 4. & Trichoderma virens & $\begin{array}{c}25.52 \\
(30.34)\end{array}$ & $\begin{array}{c}26.04 \\
(30.68)\end{array}$ & $\begin{array}{c}25.98 \\
(30.51)\end{array}$ \\
\hline 5. & Control & $\begin{array}{c}32.05 \\
(34.47)\end{array}$ & $\begin{array}{c}33.90 \\
(35.29)\end{array}$ & $\begin{array}{c}32.98 \\
(35.03)\end{array}$ \\
\hline & CD at $5 \%$ & 2.40 & 2.47 & 2.26 \\
\hline
\end{tabular}
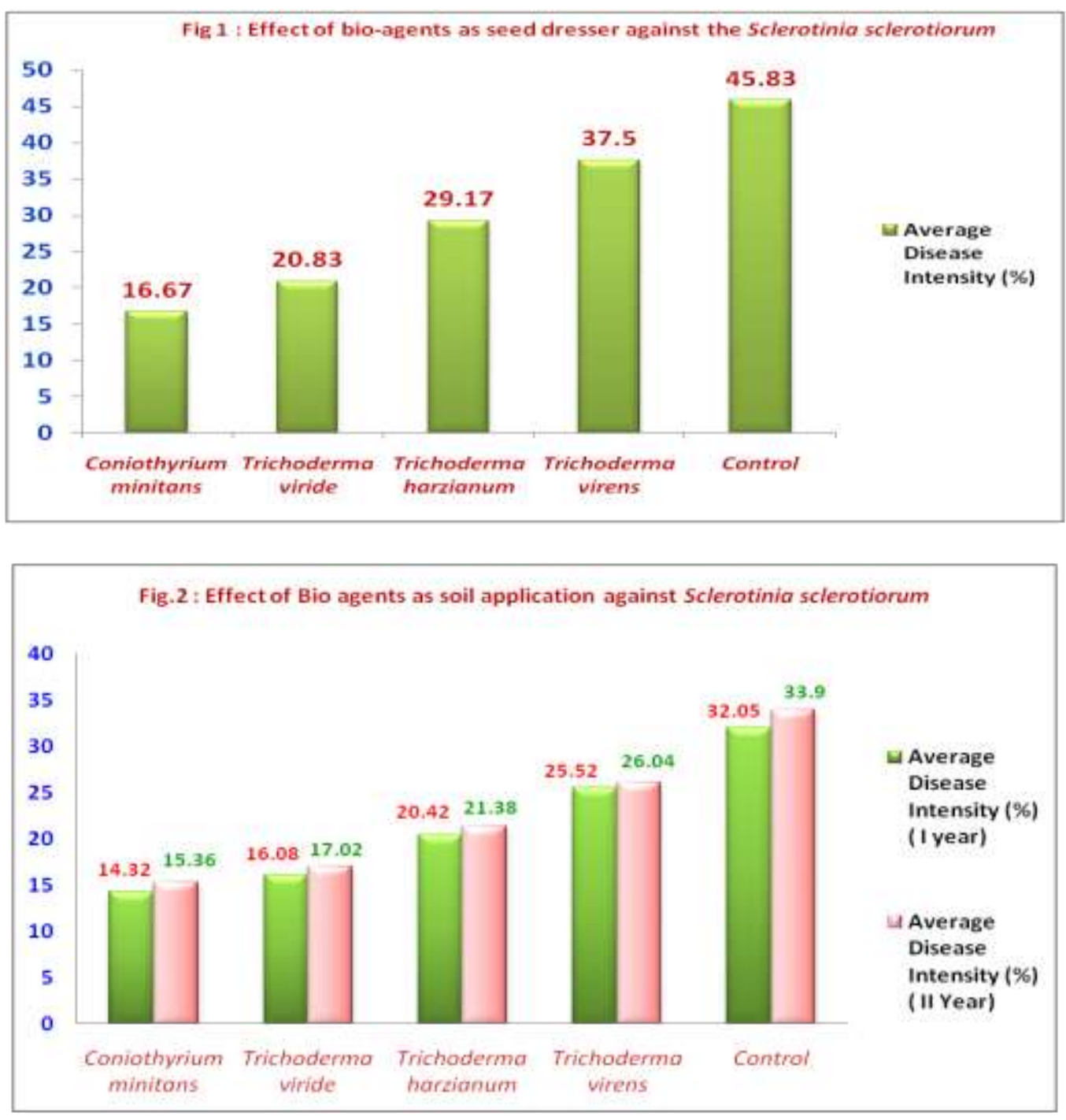
The maximum disease intensity was noticed with the formulation of Trichoderma virens treated seeds and seedlings which were least effective among all the bio-agents tested. Present findings are in accordance with the observations made by Sesan et al. (1984) who reported that soil and seed treatment with Trichoderma viride reduced the infection of sunflower by Sclerotinia sclerotiorum and Botrytis cinerea in glass house and field conditions. Similar findings were also observed by Singh (1998).

\section{Effect of bio-agents as soil application against stem rot}

It is revealed from table 3 and its corresponding figure 2 that all the bio-agents were significantly superior in controlling the disease over control. Minimum disease intensity $(14.84 \%)$ was observed in the pots treated with the formulation of Coniothyrium minitans followed by Trichoderma viride (16.55\%) as regards to the management of the disease and they were statistically at par with each other.

Trichoderma harzianum and Trichoderma virens also proved good in minimizing the disease. The results are accordance with the findings of Haung et al., (2000) who find that Coniothyrium minitans and E. pupurascens were very effective bio-agents in reducing the disease in dry bean, Singh et al. (2003) Singh et al. (2014) also reported that bio-agents like Coniothyrium minitans, Trichoderma viride, Gliocladium virens and Bacillus subtilis were effective as soil applicants in minimizing stem rot disease of Ajowan.

In conclusion, the results revealed that the Coniothyrium minitans was found very effective as seed dresser as well as soil applicant for minimizing the stem rot disease caused by Sclerotinia sclerotiorum.

\section{References}

Ahmed, A.H.M. and Tribe, H.T. 1977. Biological control of white rot of onion (Sclerotinia sclerotiorum) by Coniothyrium minitans. Plant Pathol., 26: $75-78$

Bhardwaj, S.S., Sandeep, K. and Shyam, K.R.. 1992. In vitro antagonism of soil microflora against Sclerotinia sclerotiorum. Pl. Dis. Res., 7 (1): 66-68

Budge, S.P., Mc-Quilken, M.P., Fenlon, J.S. and Whipps, J.M. 1995. Use of Coniothyrium minitans and Gliocladium virens for biological control of Sclerotinia sclerotiorum in glasshouse lettuce. Biological Control, 5: 513-522.

Dhingra, O.D. and Sinclaire, J.B. (1995). Basic Plant Pathology Methods. CRC Press INC. Boca Raton, Florida. Pp 355. Disease Control ( ${ }^{\text {rd }}$ Ed. International Science Publisher New York. 531 pp.

Jeyarajan, R. and Ramakrishnan, G. 1991. Efficacy of Trichoderma formulations against root rot disease of grain legumes. Petria, 1: 137-138.

Mc-Quilken, M.P. and Whipps, J.M. 1995. Production, survival and evaluation of solid substrate inocula of Coniothyrium minitans against Sclerotinia sclerotiorum. European J. Pl. Pathol., 101: 101-110.

Sesan, T., Iliescu, H. and Csep, N. 1984. Research in the prevention of sunflower stem and head rot using biological control. Bultinul de Protectra Plantelor, $4: 29-37$

Singh, S.B. (1998). Sclerotinia stem rot of Bishop weed and its management by bio-agents. Paper presented in $7^{\text {th }}$ International conference of Plant Pathology held in Edinburgh (U.K.) from 09-16 April, Vol. 3: 52-73

Haung, H.C., Bermer, E., Hynes. R.K. and Erikson, R.S. 2000. Foliar application of fungal bio-control agents for the 
control of white mold of drybean caused by Sclerotinia sclerotiorum. Biological Control, 18 (3): 273-274

Singh R, Udit N, Ram P. Evaluation of Bioagents against Sclerotinia stem rot of ajowan. Ann. Pl. Prot. Sci. 2003; 11:386 Singh, R., Singh, D.K. and Singh, G. 2014. Biological control of stem rots of Rajmash (Phaseolus vulgaris L.). Hort Flora Res. Spectrum, 3(2): 187-189.

\section{How to cite this article:}

Gajendra Pratap Singh and Bhupendra Kumar Singh. 2019. Evaluation of Bio-agents against Sclerotinia sclerotiorum causing Stem Rot of Broccoli. Int.J.Curr.Microbiol.App.Sci. 8(10): 2408-2413. doi: https://doi.org/10.20546/ijcmas.2019.810.279 